\title{
Plantation Silviculture of Black Locust (Robinia pseudoacacia L.) Cultivars in Hungary - A Review
}

\author{
Károly Rédei ${ }^{1,2 *}$, Zsolt Keserü², Imre Csiha², János Rásó², Veronika Honfy²
}

(1) Hungarian Horticultural Propagation Material Non-Profit Ltd., Nagytetenyi ut 306., H-1225 Budapest, Hungary; (2) National Agricultural Research and Innovation Centre, Forest Research Institute, Püspökladány Experimental Station, Farkassziget 3, H-4150 Püspökladány, Hungary

* Correspondence: e-mail: redei.karoly@t-online.hu
Citation: RÉDEI K, KESERŰ ZS, CSIHA I, RÁSÓ J, HONFY V 2017 Plantation Silviculture of Black Locust (Robinia pseudoacacia L.) Cultivars in Hungary - A Review. South-east Eur for 8 (2): 151-156. DOI: https://doi.org/10.15177/ seefor.17-11

Received: 29 May 2017; Revised: 5 Sep 2017; 22 Sep 2017: Accepted: 25 Sep 2017; Published online: 31 Oct 2017

\begin{abstract}
Background and Purpose: Black locust (Robinia pseudoacacia L.) is the most widespread tree species in Hungary, occupying approximately $24 \%$ of the forested land and providing $25 \%$ of the annual timber output of the country. Due to the demands of consumers new cultivars are to be produced by improvement techniques and introduced into practical forestry use. This review provides a practice-oriented survey on black locust cultivar's management in Hungary.

Material and Methods: There are several cultivars and cultivar-candidates for high volume, high quality saw logs; for pole and prop, fuelwood and fodder production, of which there are several multipurpose varieties. Tending guidelines of stands established with the selected black locust cultivars are in some ways different from stands established by seedlings or regenerated by coppicing.

Results and Conclusion: It is important to know how stand density influences production and how it can be manipulated. This has already been worked out for most of the major European tree species that can be grown plantation-like. Many countries have some form of production or yield models based on various spacing and thinning regimes, which are usually entered via site index curves based on height and age. Black locust plantation silviculture can come to be synonymous with high-input intensive management of monocultures for the production of a relatively narrow range of industrial products. However, there is no doubt that plantation silviculture will become increasingly important in more and more countries with special regard to the marginal site conditions.
\end{abstract}

Keywords: clonal approach, growth, growing space, yield

\section{INTRODUCTION}

Black locust (Robinia pseudoacacia L.) is the most widespread tree species in Hungary, occupying approximately $24 \%$ of the forested land (465 thousand hectares) and providing $25 \%$ of the annual timber output of the country [1]. The mean wood volume of all black locust forests is $125 \mathrm{~m}^{3} \cdot \mathrm{ha}^{-1}$, with a mean volume of $190 \mathrm{~m}^{3} \cdot \mathrm{ha}^{-1}$ at the final cutting age (31 years on average). Black locust forests in Hungary have been established on good, medium and poor quality sites. The production of good-quality timber is only possible on sites where adequate moisture is available and the soil is loose, well aerated, and rich in nutrients and organic matter. Black locust forests on medium and poor quality sites are managed for the production of fuel wood, fodder, poles, props, and for amelioration [2, 3].
Black locust can be regenerated naturally, from root suckers, or artificially, with seedlings. To establish new black locust plantations (stands) seedlings are used. There are some favourable biological features of black locust, which make both regeneration methods possible. For seedlings production seeds are produced in a wide range of climatic conditions, they germinate rapidly, and preserve their germination capacity for a long time. Black locust cannot be regenerated by seeds in natural way due to its very hard seed coat. On the other hand, the root system is very plastic, its vegetative growth from fragments is intensive and it is hard to uproot [4].

Besides Hungary, Romania, and Bulgaria where black locust has a great importance in forestry practice, there are 
two big regions where the fast spread of this tree species can be expected: in the Mediterranean countries of Europe (Italy, Greece and Turkey) and in Asia, where China and Korea may be the most prominent black locust growers. In these regions, black locust has been widely valued as a tree species that performs well in reclaiming disturbed lands as well [5].

\section{MATERIAL AND METHODS}

\section{Black Locust Selection Programme in Hungary}

Since the introduction of black locust into Hungary this tree species has been closely associated with agriculture, since its wood can be utilized for many agricultural and domestic purposes. After World War II its significance changed, because large-scale farms had less demand for wood and the timber industry was not willing to buy black locust wood. It was necessary to improve the quality of final products of black locust forests in order to meet the demands of consumers. Therefore, new cultivars had to be produced by improvement techniques introducing them into the practical forestry use [5].

To fulfil the above-mentioned tasks, a new strategy of several stages started in the Hungarian Forest Research Institute in 1961. The improvement strategy aimed to improve the quality of black locust stands, which were considered to be separate provenances. In the best black locust stands, tree groups of shipmast stem forms, and then plus trees were selected by B. Keresztesi and his colleagues [6]. The offspring of these selected trees were vegetatively propagated and grouped together into cultivars. Thus, cultivars are mostly composed of several clones, but there are also some one-clone-cultivars, too [7].

Grafts with shoots taken from plus trees were made and planting stocks were raised from them by green cuttings. The basic material produced in this way served as starting material with the help of a variety trial established in the Arboretum of the Hungarian Forest Research Institute in Gödöllö, on a rusty brown forest soil developed over sand. The development of this trial continues up to date. In the meantime, breeding aims were widened by taking the demands of bee-keeping into consideration, such as the onset and length of flowering, and nectar yields [6, 8]. Some trees were selected abroad and others in Hungary and were chosen by beekeepers, due to their excellent honey production.

The main target of improvement is to improve the quality of stem, so to increase the output of industrial wood. Based on timber volume at felling age the following cultivars may be assessed as best: 'Jászkiséri', 'Üllôi', 'Nyirségi', 'Kiskunsági', 'Kiscsalai' and 'Pénzesdombi'. At the moment 7 black locust cultivars are approved by the competent Hungarian national office.

Propagation of cultivars was first planned by seedlings, but seed orchards produced small quantities of seed, and therefore it was necessary to develop techniques for vegetative propagation (with green cuttings, root cuttings and micropropagation) [6].
Site Requirements for Successful Black Locust Plantation Silviculture

The variable nature of geographical conditions in Hungary and the large area of black locust stands have made it possible to determine its site demands and to characterize suitable sites. This task has been solved by the Hungarian system for forest site classification $[9,10]$. The classification is based on four dominant factors, which are: climate, hydrologic conditions (non-precipitation water resources, such as ground-water, inundation waters etc.), genetic soil type, physical make up and rootable depth.

The climatic conditions in the sessile oak - Turkey oak (Table 1) and forest-steppe zones of Hungary (Table 2) cover the black locust's requirements [11]. It is susceptible to late and early frosts, and therefore it is not recommended for sites in higher hilly zones and in areas where frost hollows are present. Good results can be attained in regions where the mean annual temperature is over $8^{\circ} \mathrm{C}$.

The genetic soil type, soil depth and physical properties of the soil are the factors which must be regarded before the planting operation as well. From this point of view soils of shallow rootable depth, of poor water regime and coarse sand or with many stones are unfavourable. Clay texture is also unfavourable due to poor aeration and compact condition. Fine sands and light loamy soil types are good for black locust, provided the depth of the soil is enough [10].

\section{RESULTS}

Recommendations for Tending Operations (Enlargement of Growing Space) for Black Locust Cultivar Plantations

Tending guidelines of stands established with the selected black locust cultivars are in some ways different from the stands established by seedlings or regenerated by coppicing. It is harder to separate the tending phases (cleaning, thinning), which are typical for common black locust stands, because growth properties of monoclonal cultivars are theoretically identical, while multiclonal ones are similar to each another. The aim of certain tending cuttings particularly is to form the growing space for optimal growth of the trees [12].

On good and excellent sites altogether two enlargements of growing space are applicable to produce basic material of sawmilling industry in stands planted in $2.5 \times 2.0 \mathrm{~m}$ spacing $\left(5 \mathrm{~m}^{2}\right.$.tree growing space ${ }^{-1}$ ) (Table 3$)$. During the first enlargement of the growing space (at the age of 9-10) stem number reduction is approximately $50 \%$, so spacing will be $2.5 \times 4.0 \mathrm{~m}\left(10 \mathrm{~m}^{2}\right.$.tree growing space $\left.\mathrm{e}^{-1}\right)$ after the tending. The second enlargement of the growing space (at the age of 16-17) also reduces the number of stems by $50 \%$. During this, the greater part of the yield is already suitable for industrial utilization, so growing technology can be considered economically profitable.

Prospective tree plantations of the selected black locust cultivars with tending according to the demonstrated model in Table 4 are rentable only on excellent and good sites. In case of planning to reduce harvest rotation ages (20-25 years) the aim of the growing can be manufacturing pole, or saw log of lower size limit. 
TABLE 1. Site types suitable for black locust in the sessile oak - Turkey oak climate zone [8].

\begin{tabular}{|c|c|c|c|c|}
\hline \multicolumn{4}{|c|}{ Site type variety } & \multirow{2}{*}{$\begin{array}{l}\text { Expected yield and } \\
\text { rotation age }\end{array}$} \\
\hline Genetic soil type & Hydrology & Rootable depth & Physical make-up & \\
\hline Humic sand & free draining & shallow & sand & poor \\
\hline Rusty brown forest soil & free draining & $\begin{array}{c}\text { shallow } \\
\text { medium deep } \\
\text { deep }\end{array}$ & $\begin{array}{l}\text { sand } \\
\text { sand } \\
\text { sand } \\
\text { loam }\end{array}$ & $\begin{array}{c}\text { poor } \\
\text { medium, } 25 \text { years } \\
\text { good, } 30 \text { years } \\
\text { good, } 30 \text { years }\end{array}$ \\
\hline „Kovárvány” brown forest soil & free draining & $\begin{array}{l}\text { shallow } \\
\text { medium deep } \\
\text { deep }\end{array}$ & $\begin{array}{l}\text { sand } \\
\text { sand } \\
\text { sand }\end{array}$ & $\begin{array}{c}\text { medium, } 25 \text { years } \\
\text { good, } 30 \text { years } \\
\text { good, } 30 \text { years }\end{array}$ \\
\hline Chernozem brown forest soil & free draining & $\begin{array}{l}\text { shallow } \\
\text { medium deep }\end{array}$ & $\begin{array}{l}\text { loam } \\
\text { loam }\end{array}$ & $\begin{array}{c}\text { poor } \\
\text { medium, } 25 \text { years }\end{array}$ \\
\hline $\begin{array}{l}\text { Brown forest soil with residual } \\
\text { carbonate }\end{array}$ & free draining & medium deep & $\begin{array}{l}\text { loam } \\
\text { loam }\end{array}$ & $\begin{array}{l}\text { medium, } 25 \text { years } \\
\text { good, } 30 \text { years }\end{array}$ \\
\hline Colluvial forest soil & free draining & medium deep & loam & good, 30 years \\
\hline Rusty brown forest soil & periodic water influence & $\begin{array}{l}\text { medium deep } \\
\text { deep }\end{array}$ & $\begin{array}{l}\text { sand } \\
\text { sand }\end{array}$ & $\begin{array}{l}\text { good, } 25 \text { years } \\
\text { good, } 30 \text { years }\end{array}$ \\
\hline „Kovárvány” brown forest soil & periodic water influence & $\begin{array}{l}\text { medium deep } \\
\text { deep }\end{array}$ & $\begin{array}{l}\text { sand } \\
\text { sand }\end{array}$ & $\begin{array}{l}\text { good, } 25 \text { years } \\
\text { good, } 30 \text { years }\end{array}$ \\
\hline Meadow soil & periodic water influence & shallow & sand & medium, 25 years \\
\hline Meadow forest soil & periodic water influence & medium deep & sand & medium, 25 years \\
\hline
\end{tabular}

TABLE 2. Black locust site types in the forest-steppe climate region [8].

\begin{tabular}{|c|c|c|c|c|}
\hline \multicolumn{4}{|c|}{ Site type variety } & \multirow{2}{*}{$\begin{array}{l}\text { Expected yield and } \\
\text { rotation age }\end{array}$} \\
\hline Genetic soil type & Hydrology & Rootable depth & Physical make-up & \\
\hline Humic sand combinations & free draining & $\begin{array}{l}\text { medium deep } \\
\text { deep } \\
\text { very deep }\end{array}$ & $\begin{array}{l}\text { sand } \\
\text { sand } \\
\text { sand }\end{array}$ & $\begin{array}{c}\text { poor } \\
\text { medium, } 25 \text { years } \\
\text { good, } 30 \text { years }\end{array}$ \\
\hline Colluvial soil & free draining & medium deep & $\begin{array}{l}\text { sand } \\
\text { loam }\end{array}$ & $\begin{array}{l}\text { medium, } 25 \text { years } \\
\text { medium, } 25 \text { years }\end{array}$ \\
\hline Rusty brown forest soil & free draining & $\begin{array}{c}\text { medium deep } \\
\text { deep }\end{array}$ & $\begin{array}{l}\text { sand } \\
\text { sand }\end{array}$ & $\begin{array}{c}\text { poor (afforestation) } \\
\text { medium, } 25 \text { years }\end{array}$ \\
\hline „Kovárvány” brown forest soil & free draining & $\begin{array}{l}\text { medium deep } \\
\text { deep }\end{array}$ & $\begin{array}{l}\text { sand } \\
\text { sand }\end{array}$ & $\begin{array}{c}\text { poor (afforestation) } \\
\text { medium, } 25 \text { years }\end{array}$ \\
\hline Leached chernozem soil & free draining & $\begin{array}{c}\text { medium deep } \\
\text { deep } \\
\text { very deep }\end{array}$ & $\begin{array}{l}\text { loam } \\
\text { loam } \\
\text { loam }\end{array}$ & $\begin{array}{c}\text { medium, } 25 \text { years } \\
\text { good, } 30 \text { years } \\
\text { good, } 30 \text { years }\end{array}$ \\
\hline Lime-carbonate coated chernozem & free draining & $\begin{array}{l}\text { medium deep } \\
\text { deep }\end{array}$ & $\begin{array}{l}\text { loam } \\
\text { loam }\end{array}$ & $\begin{array}{c}\text { medium, } 25 \text { years } \\
\text { good, } 30 \text { years }\end{array}$ \\
\hline Meadow chernozem & free draining & $\begin{array}{l}\text { medium deep } \\
\text { deep } \\
\text { very deep }\end{array}$ & $\begin{array}{l}\text { loam } \\
\text { loam } \\
\text { loam }\end{array}$ & $\begin{array}{l}\text { medium, } 25 \text { years } \\
\text { good, } 30 \text { years } \\
\text { good, } 30 \text { years }\end{array}$ \\
\hline Alluvial chernozem soil & free draining & $\begin{array}{l}\text { medium deep } \\
\text { deep } \\
\text { very deep }\end{array}$ & $\begin{array}{l}\text { sand } \\
\text { loam } \\
\text { sand } \\
\text { loam } \\
\text { sand } \\
\text { loam }\end{array}$ & $\begin{array}{c}\text { medium, } 25 \text { years } \\
\text { medium, } 25 \text { years } \\
\text { good, } 30 \text { years } \\
\text { good, } 30 \text { years } \\
\text { good, } 30 \text { years } \\
\text { good, } 30 \text { years }\end{array}$ \\
\hline
\end{tabular}

\section{Yield of the Selected Black Locust Cultivars}

Based on growth examinations of the selected black locust cultivars, mainly with shipmast locust character, characteristics of their growth pattern are similar to the common black locust's [8]. A yield table has been compiled for those black locust cultivars that are suitable for log production ('Nyírségi', 'Kiskunsági', 'Jászkiséri', 'Appalachia', 'Üllöi' black locust) by using the data of the growing trial established in the Arboretum of the Forest Research Institute in Gödöllö, and other areas of the country (Tét, Szentkirály, 
TABLE 3. Models of enlargement of the growing space of the selected black locust cultivars. The aim of growing: saw log. Initial spacing: $2.5 \times 2.0 \mathrm{~m}$. Initial number of seedlings: 2000 stems $\cdot \mathrm{ha}^{-1}[3]$.

\begin{tabular}{|c|c|c|c|c|c|c|}
\hline & Label & $\begin{array}{c}\text { Age } \\
\text { (year) }\end{array}$ & $\begin{array}{c}\mathbf{H} \\
(\mathrm{m})\end{array}$ & $\begin{array}{l}\text { DBH } \\
(\mathrm{cm})\end{array}$ & $\underset{\left(\text { stems } \cdot h a^{-1}\right)}{\mathbf{N}}$ & $\begin{array}{c}\mathbf{V} \\
\left(\mathrm{m}^{3} h \mathrm{a}^{-1}\right)\end{array}$ \\
\hline \multicolumn{7}{|c|}{ Yield Class I } \\
\hline 1. & Enlargement of growing space & $9-10$ & 14 & 12 & 1000 & 90 \\
\hline 2. & Enlargement of growing space & $16-17$ & 20 & 17 & 500 & 120 \\
\hline 3. & Harvest cutting & 30 & 25 & 25 & 400 & 300 \\
\hline \multicolumn{7}{|c|}{ Yield Class II } \\
\hline 1. & Enlargement of growing space & $9-10$ & 14 & 12 & 1000 & 90 \\
\hline 2. & Enlargement of growing space & $16-17$ & 20 & 17 & 500 & 120 \\
\hline 3. & Harvest cutting & 30 & 25 & 25 & 400 & 300 \\
\hline \multicolumn{7}{|c|}{ Yield Class III } \\
\hline 1. & Enlargement of growing space & $9-10$ & 12 & 10 & 1000 & 60 \\
\hline 2. & Enlargement of growing space & $16-17$ & 18 & 16 & 500 & 100 \\
\hline 3. & Harvest cutting & 30 & 23 & 23 & 500 & 240 \\
\hline
\end{tabular}

$\mathrm{H}$ - height; DBH - diameter at breast height; $\mathrm{N}$ - number of stems per hectare; $\mathrm{V}$ - expected total volume

Notation: Data are referred to the dominant stand, that is stand part, after finishing enlargements of the growing space. Yield table: Rédei et al. [8].

TABLE 4. Models of enlargement of the growing space of plantations established by the selected black locust cultivars. The aim of growing: poles, perspectively saw log. Initial spacing: $3.0 \times 3.0 \mathrm{~m}$. Initial number of seedlings: $1100 \mathrm{stems} \cdot \mathrm{ha}^{-1}$ [3].

\begin{tabular}{|c|c|c|c|c|c|}
\hline Label & $\begin{array}{c}\text { Age } \\
\text { (year) }\end{array}$ & $\begin{array}{c}\mathbf{H} \\
(\mathrm{m})\end{array}$ & $\begin{array}{l}\text { DBH } \\
(\mathrm{cm})\end{array}$ & $\underset{\left(\text { stems } \cdot h a^{-1}\right)}{\mathbf{N}}$ & $\begin{array}{c}\mathbf{V} \\
\left(\mathrm{m}^{3} h \mathrm{a}^{-1}\right)\end{array}$ \\
\hline \multicolumn{6}{|c|}{ Model I } \\
\hline Before enlargement of growing space & 10 & 13 & 10 & 1100 & 65 \\
\hline After enlargement of growing space & 10 & 14 & 11 & 700 & 55 \\
\hline Harvest cutting & 20 & 20 & 18 & 700 & 180 \\
\hline \multicolumn{6}{|c|}{ Model II } \\
\hline Before enlargement of growing space & 8 & 10 & 8 & 1100 & 40 \\
\hline After enlargement of growing space & 8 & 11 & 9 & 750 & 35 \\
\hline Before enlargement of growing space & 15 & 17 & 14 & 750 & 105 \\
\hline After enlargement of growing space & 15 & 18 & 15 & 500 & 85 \\
\hline Harvest cutting & 25 & 22 & 20 & 500 & 180 \\
\hline
\end{tabular}

$\mathrm{H}$ - height; $\mathrm{DBH}$ - diameter at breast height; $\mathrm{N}$ - number of stems per hectare; $\mathrm{V}$ - expected total volume

Ófehértó). Table 5 shows informative data on the yields of the main stands of selected black locust cultivars suitable for saw log production.

Height growth related to the age of the main (dominant) stands of the mentioned cultivars can be seen in Figure 1 for five yield classes. The explanatory equation of the relative growth pattern is:

$H_{\text {gmean }}=19.4669-57.08546 \times[\log (A)]+73.57742 \times$

$[\log (A)] 22.80025 \times[\log (A)] 3+28.08599 \times x[\log (A)] 4$,

where: $A=$ age (year), and $H_{\text {gmean }}$ at the age of $20=100 \%$.

Height values at the age of 20 (base age, 100\%) are: yield class I: $22 \mathrm{~m}$; yield class II: $20 \mathrm{~m}$; yield class III: $18 \mathrm{~m}$; yield class IV: $16 \mathrm{~m}$; yield class V: $14 \mathrm{~m}$.

Volumes related to the age of the main stands of the same varieties are shown in Figure 2. The explanatory equation for describing the relationship between mean height $\left(\mathrm{H}_{\text {mean }}\right)$ and volume $\left(\mathrm{V}_{\text {mean }}\right)$ is the following:

$$
\mathrm{V}_{\text {mean }}=23.750-2.325 \mathrm{H}_{\text {mean }}+0.512 \mathrm{H}_{\text {mean }}^{2}
$$

\section{DISCUSSION AND CONCLUSIONS}

Since spacing influences the total production and the dimensions of forest products, it can have a profound effect on the value of a crop. It is important to know how stand density influences production and how it can be manipulated.

In practice, there are two main aspects of spacing to consider - the effects of early or initial spacing and the effects of thinning. Initial spacing are quite often the densities at which plantations remain, except for mortality, especially where thinning is uneconomic or leads to windthrow. Since the initial spacing of forestation by the selected black locust cultivars is concerned with the basis 
FIGURE 1. Height of the main stands of the selected black locust cultivars for saw log production related to the age in different yield classes.

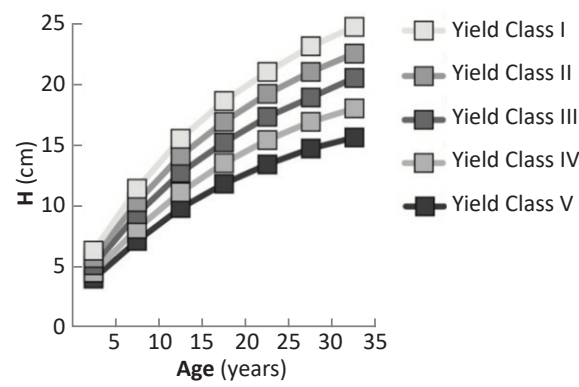

FIGURE 2. Volume of the main stand of the selected black locust cultivars for saw log production in different yield classes.

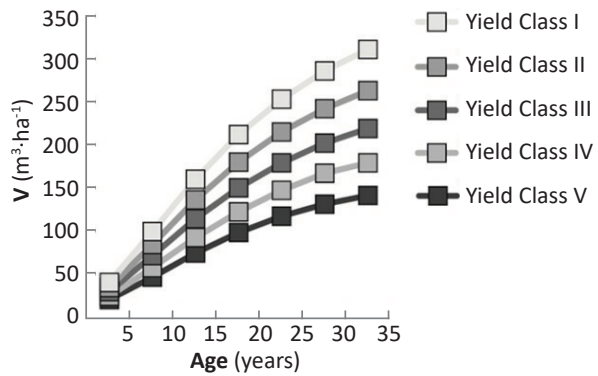

TABLE 5. Yield of the main stands of the selected black locust cultivars suitable for saw log production [3].

\begin{tabular}{|c|c|c|c|c|c|c|}
\hline Yield class & $\begin{array}{c}\text { Age } \\
\text { (year) }\end{array}$ & $\begin{array}{l}\text { Mean DBH } \\
(\mathrm{m})\end{array}$ & $\begin{array}{c}\text { Mean H } \\
(\mathrm{m})\end{array}$ & $\begin{array}{c}\mathbf{V} \\
\left(\mathrm{m}^{3} \cdot h \mathrm{a}^{-1}\right)\end{array}$ & $\begin{array}{c}\mathbf{G} \\
\left(\mathrm{m}^{2} \cdot \mathrm{ha}^{-1}\right)\end{array}$ & $\left.\underset{(\text { stems }}{\mathbf{N}} \mathrm{ha}^{-1}\right)$ \\
\hline \multirow{7}{*}{1} & 5 & 8.7 & 6.4 & 40 & 7.5 & 2327 \\
\hline & 10 & 14.8 & 11.5 & 99 & 12.6 & 1214 \\
\hline & 15 & 19.2 & 15.6 & 160 & 16.5 & 863 \\
\hline & 20 & 22 & 18.7 & 212 & 19.4 & 703 \\
\hline & 25 & 23.8 & 21.2 & 253 & 21.6 & 612 \\
\hline & 30 & 25 & 23.2 & 286 & 23.4 & 554 \\
\hline & 35 & 25.7 & 24.8 & 311 & 24.9 & 513 \\
\hline \multirow{7}{*}{ II } & 5 & 7.9 & 5.8 & 34 & 6.9 & 2588 \\
\hline & 10 & 13.5 & 10.4 & 84 & 11.5 & 1350 \\
\hline & 15 & 17.4 & 14.2 & 136 & 15.1 & 960 \\
\hline & 20 & 20 & 17 & 180 & 17.8 & 782 \\
\hline & 25 & 21.7 & 19.3 & 215 & 19.9 & 681 \\
\hline & 30 & 22.7 & 21.1 & 242 & 21.5 & 616 \\
\hline & 35 & 23.4 & 22.6 & 263 & 22.9 & 571 \\
\hline \multirow{7}{*}{ III } & 5 & 7.1 & 5.2 & 29 & 6.2 & 2911 \\
\hline & 10 & 12.1 & 9.4 & 71 & 10.5 & 1518 \\
\hline & 15 & 15.7 & 12.8 & 114 & 13.9 & 1080 \\
\hline & 20 & 18 & 15.3 & 150 & 16.2 & 880 \\
\hline & 25 & 19.5 & 17.4 & 179 & 18.2 & 766 \\
\hline & 30 & 20.5 & 19 & 202 & 19.6 & 693 \\
\hline & 35 & 21 & 20.6 & 219 & 20.8 & 642 \\
\hline \multirow{7}{*}{ IV } & 5 & 6.3 & 4.6 & 24 & 5.6 & 3374 \\
\hline & 10 & 10.6 & 8.2 & 57 & 9.3 & 1769 \\
\hline & 15 & 13.8 & 11.2 & 92 & 12.3 & 1249 \\
\hline & 20 & 16 & 13.6 & 122 & 14.6 & 1006 \\
\hline & 25 & 17.4 & 15.5 & 147 & 16.4 & 869 \\
\hline & 30 & 18.3 & 17 & 167 & 17.8 & 784 \\
\hline & 35 & 18.7 & 18.1 & 179 & 18.8 & 731 \\
\hline \multirow{7}{*}{ V } & 5 & 5.6 & 4.1 & 20 & 5.1 & 3834 \\
\hline & 10 & 9.3 & 7.2 & 46 & 8.3 & 2046 \\
\hline & 15 & 12.1 & 9.9 & 74 & 11 & 1343 \\
\hline & 20 & 14 & 11.9 & 98 & 13 & 1168 \\
\hline & 25 & 15.2 & 13.5 & 117 & 14.5 & 1014 \\
\hline & 30 & 15.9 & 14.8 & 131 & 15.7 & 915 \\
\hline & 35 & 16.2 & 15.7 & 141 & 16.6 & 857 \\
\hline
\end{tabular}


of growing experiments in the Danube-Tisza sandy soil region (Central Hungary) and in the Nyírség (East Hungary), $2.5 \times 2.0 \mathrm{~m}$ spacing seems to be most appropriate [12]. In forestation, those are established on sites that expectedly enable medium growing (the cultivars) varieties in wider spacing than the recommended which cannot close sufficiently because of their loose crown. Therefore, the soil is extremely weedy, even in the case of soil cultivation that corresponds to regulation, too.

It is very important to execute the stem and crown shaping according to the technological prescription. In base spacing recommended by us [5], first crown shaping is to be carried out when the mean height of the plantation reaches 5-6 metres. The second crown shaping should be done in time when the mean height of the plantation is 8-10 metres (reach of about $4 \mathrm{~m}$ branch-free stem is desired).

Forest tending technologies applicable for different cultivars have not yet been elaborated sufficiently. A useful indicator of the size of the removed tree, and hence for describing the thinning type, is the ratio of the mean volume of thinnings (v) to the mean volume of the main stand found before thinning (V) [5]. There are three types of thinning which can be distinguished: systematic, selective and combination [6]. According to our experiences the selective thinning method is to be used mostly in the plantations established with selected black locust cultivars. The best trees (superior trees) are marked when they are young and favoured in subsequent thinnings. Because some inevitably become damaged or do net grow as well as expected, it is necessary to work at the outset two or three times the number that will actually form the final crop.

Black locust plantation silviculture can come to be synonymous with high-input intensive management of monocultures for the production of a relatively narrow range of industrial products. But, there is no doubt that plantation silviculture will become increasingly important in even more countries with special regard to the marginal site conditions.

At the moment the total area of black locust globally is about 2.5 million ha. In the near future there are two continents, where the fast spread of black locust can be expected. The first is the Asian continent, in China and South and North Korea, while in the European continent France, Turkey, Romania and Germany may be the most prominent black locust growers.

\section{REFERENCES}

1. RÉDEI K, KESERÛ ZS, ANTAL B 2015 Tending operation models for black locust (Robinia pseudoacacia L.) stands growing on sandy soils in Hungary. International Journal of Horticultural Science 21 (3-4): 55-57

2. RÉDEI K, OSVÁTH-BUJTÁS Z, VEPERDI I 2008 Black Locust (Robinia pseudoacacia L.) Improvement in Hungary: a Review. Acta Silvatica et Lignaria Hungarica 4: $127-132$

3. RÉDEI K, OSVÁTH-BUJTÁS Z, BALLA I 2001 Propagation methods for black locust (Robinia pseudoacacia L.) improvement in Hungary. Journal of Forestry Research, 12 (4): 215-219. DOI: https://doi.org/10.1007/BF02856710

4. RÉDEI K, CSIHA I, KESERÚ ZS, GÁL J 2012 Influence of Regeneration Methods on the Yield of Black Locust (Robinia pseudoacacia L.) Stands: a Case Study. Acta Silvatica et Lignaria Hungarica 8 (1): 103-111. DOI: DOI: https://doi.org/10.2478/v10303-012-0008-1

5. RÉDEI K (ed) 2013 Black locust (Robinia pseudoacacia L.) growing in Hungary. Hungarian Forest Research Institute, Agroinform Kiadó, Budapest, Hungary, $78 \mathrm{p}$

6. KERESZTESI B 1988 The Black Locust. Akadémiai Kiadó, Budapest, Hungary, $196 \mathrm{p}$
7. RÉDEI K, OSTVÁTH-BUJTÁS Z, BALLA । 2002 Clonal approaches to growing black locust (Robinia pseudoacacia) in Hungary: a review. Forestry 75(5): 548552. DOI: https://doi.org/10.1093/forestry/75.5.547

8. RÉDEI K (ed) 1998 Black locust growing in Hungary. Publications of the Hungarian Forest Research Institute, Budapest, Hungary, $51 \mathrm{p}$

9. JÁRÓ Z 1968 The fundamental principles of the sitetypological systematisation. Kísérleti Közlemények, 61/D, 1-3: $11-25$

10. FÜHRER E 1998 Characterization of black locust from ecological aspects. In: Rédei K. (ed): Black locust growing in Hungary. Publications of the Hungarian Forest Research Institute, Budapest, Hungary, pp 10-12

11. JÁRÓ Z 1984 Az akác termőhelye, felújítása és telepítése. In: Keresztesi B (ed) Az akác termesztése és hasznosítása. Mezőgazdasági Kiadó, Budapest, Hungary

12. RÉDEI K, CSIHA I, KESERÚ Z, RÁSÓ J, KAMANDINÉ VÉGH Á, ANTAL B 2014 Growth and Yield of Black Locust (Robinia pseudoacacia L.) Stands in Nyírség Growing Region (North-East Hungary). South-east European Forestry 5 (1): 13-22. DOI: https://doi.org/10.15177/ seefor.14-04 